\title{
A study on the alienation of physical activity participation of adults with adventitious visual impaimment
}

\author{
Ga-ram $\mathrm{Jo}^{1}$, Joon-sik Kim², Yeon-soo $\mathrm{Kim}^{2}$, In-hwan $\mathrm{Cho}^{3}$, Dae-joong $\mathrm{Ma}^{4}$, \\ Woon-hyung Ghim ${ }^{5}$, In-hwan Hong ${ }^{6}$, \& Hyeong-Gon $\mathbf{Y u}^{2 *}$ \\ ${ }^{1}$ Korea Nazarene University, ${ }^{2}$ Seoul National University, ${ }^{3}$ Soonchunhyang University Hospital Cheonan, \\ ${ }^{4}$ Jeju National University Hospital, ${ }^{5}$ Sinchon Ghim's Eye Clinic \& ${ }^{6}$ Dongtan Sacred Heart Hospital
}

\begin{abstract}
[Purpose] The purpose of this study is to investigate the alienation and the overcoming process of the physical activity participation of people with Adventitious Visual Impairment(AVI) [Methods] 21 Adults with AVI were recruited and one on one semi-structured interview was conducted. Ground theory was used to analyze the data. Member check, peer debriefing was conducted to enhance the trustworthiness of this study. [Results] As a result, a total of 203 concepts were derived. This consisted of 21 subcategories and the common themes of the subcategories were categorized into nine categories. Specific results are as follows. First, the physical activity of people with AVI was directly affected by the sports facilities, physical activity programs, and professional instructor. This causal condition resulted in the loss of leisure experience in the context of the busy daily life and the depressed psychological state. Second, due to the perceived need of health care and the positive involvement of others, people with AVI came to expect the effect of exercise. Third, people with AVI participated in physical activity again as a tool to achieve the purpose of health improvement. This type of physical activity has a limitation that it can not guarantee the continuity of physical activity due to the limitation that it does not contain autonomy and interest of people with AVI. [Conclusion] Based on these results, the following suggestions were made. First, it is necessary to improve the environment for ensuring participation in physical activity of people with AVI. Moreover education and promotion of the effects and values of the exercise should be carried out for people with AVI and their guardians. Second, it is necessary to diversify physical activity types and reconstruct existing exercise programs.
\end{abstract}

Key words: People with Adventitious Visual Impairment, Alienation, Physical Activity

\section{서 론 \\ 인구고령화에 따른 만성질환의 증가와 산업화에 따른 각종 사고의 증가로 장애인의 수는 지속적으로 증가해왔}

논문 투고일 : 2019. 12. 10.

논문 수정일 : 2020. 02. 10 .

게재 확정일 : 2020. 03. 05.

* 교신저자 : 유형곤(hgonyu@snu.ac.k).
다. 2017년 보건복지부의 장애인 실태에 따르면 장애발 생은 주로 후천적 원인(88.1\%)에 의한 것으로 보고되었 다(Ministry of Health and Welfare, 2017). 시각장애 인의 증가 경향도 이와 마찬가지이며, 우리나라의 시각장 애인은 전체 장애인인구의 $9.8 \%$ 를 차지하고 있다. 시각 장애 발생시기는 $92.6 \%$ 가 돌 이후인 것으로 보고되고 있 기 때문에 후천성 중도 시각장애인이 시각장애인구의 다 수를 차지한다고 할 수 있다(Lee \& Ye, 2016). 
태어나면서부터 시력을 상실한 선천적 시각장애인과 달리, 과거에 시력에 문제가 없다가 후천적으로 시력을 상실하게 되는 중도 장애인의 경우 정체성을 형성하고 인 생의 설계기라 할 수 있는 청년기나 사회활동이 왕성한 장년기에 실명을 경험하게 된다. 이 때문에 중도시각장애 인 당사자는 물론 주변가족들은 심각한 충격과 사회부적 응을 경험할 수밖에 없으며 (Kim \& Kim, 2008), 비장애 인들보다 심각한 스트레스와 우울증에 시달리고 있음과 동시에 더 빈번하게 자살 충동을 느끼는 것으로 보고되고 있다(Kim et al, 2013).

신체활동이 성별, 나이, 인종, 그리고 장애에 상관없이 많은 건강상, 정서적 이점을 제공한다는 것은 이미 수많 은 연구를 통해 입증되어 왔다. 그러나, 장애인의 경우, 신체적 손상으로 인해 추가적인 도움이 필요함에도 불구 하고 장애를 이유로 신체활동 참여 기회로부터 소외되어 왔으며 이러한 불평등은 점차 심각한 사회 문제로 대두되 고 있다. 이러한 맥락에서 시각장애인들의 신체활동량은 비장애인들보다 매우 저조한 수준인 것으로 보고되고 있 다(Kozub \& Oh, 2004). 문제의 심각성은 이들이 나이 가 들수록 더 비 신체활동적인 생활습관을 유지하게 된다 는 것이다(Ayvazoglu, Oh, \& Kozub, 2002). 그 결과로 중도시각장애인들의 삶의 질은 매우 낮을 뿐만 아니라 여 러 가지 심각한 신체적·정신적 건강 위협에 직면하게 된 다(Haegele \& Porretta, 2015; Haegele \& Zhu, 2019). 따라서, 중도시각장애인들의 신체활동을 증진 시 키는 것은 매우 중요하며 이를 위해서는 현재 왜 우리나 라의 중도시각장애인이 신체활동에 참여하지 못하고 소 외될 수밖에 없는가에 대한 경험적 자료에 근거한 답이 요청된다.

중도 시각장애인의 신체활동과 관련한 연구들이 국외 에서는 비교적 활발하게 이루어졌지만, 대다수가 학령기 아동을 대상으로 진행되었거나 단순 설문방법을 통해 이 루어져 시각장애인 신체활동 소외 원인을 아동에 한정하 여 단편적으로 제시하는데 그치고 있다. 국내 성인 중도 시각장애인의 관련연구는 대부분이 실명의 고통과 이를 극복하는 과정에 대한 연구(Kim \& Yoo, 2018; Song \& Oh, 2017)들이 주를 이루었으며, 신체활동과 관련하여 이루어진 연구는 소수에 불과했다. 소수의 연구마저 (Kim \& Han, 2008; Kim \& Kim 2008; Geon et al,
2017) 스포츠를 통한 사회화나 현실수용과 같이 스포츠 활동의 유익에 초점 두고 진행되었기 때문에 중도시각장 애인들이 신체활동에서 소외되는 원인과 과정에 대한 이 해를 제시하지는 못하였다. 신체활동이라는 현상이 특정 생활세계의 문화적 배경을 바탕으로 이루어진다는 점을 고려하면 이는 국내 시각장애인의 신체활동에 대한 학술 적 이해 수준은 아직 초보적 수준에 머물러 있다는 것을 시사한다. 본 연구는 이러한 선행연구들의 제한점을 보완 하여 중도 성인 시각장애인을 연구참여자로 선정하여 이 들의 신체활동 소외 경험을 이해하고자 하였으며, 질적 연구의 전통 중 하나인 근거이론 연구방법을 통해 중도시 각장애인의 신체활동 현상에 대한 총제적이고 깊이 있는 설명을 제시하고자 하였다.

\section{연구방법}

\section{연구참여자}

본 연구 참여자는 사회생활 경험이 있는 성인 이력성 중도시각장애인이다. 연구참여자 모집을 위해 $\mathrm{A}$ 대학 병 원에 연구 목적을 밝히고 연구 참여자 모집 문건, 연구요 약서, 연구 참여 동의서를 첨부하여 적합한 연구 참여자 추천을 의뢰하였다. 연구참여자는 보건복지부 기준 시각 장애등급 6 급 이상의 판정을 받은 성인 중도시각장애인 으로 한정하였다. 그 결과 $\mathrm{A}$ 대학의 병원으로부터 총 40 명의 만성질환에 의한 중도시각장애인을 추천받을 수 있 었으며, 추천명단에 있는 대상에게 전화로 연구일정과 연 구목적 및 내용을 밝히고 연구 참여를 의뢰하였다. 이중 총 21 명이 연구참여에 동의하였으며 최종으로 선정된 연 구참여자들에게는 서면으로 연구동의서를 받았다. 연구 참여자의 일반적 특성은 다음 〈Table 1)과 같다.

\section{자료 수집 및 자료분석}

본 연구의 자료수집은 반구조화(semi-structured) 질 문지를 바탕으로 진행한 심층면담을 통해 이루어졌다. 면 담은 근거이론 연구에서 연구참여자의 내적 세계를 이해 하고 발견하기에 가장 적절한 자료 수집 방법으로 여겨진 다(Strauss \& Corbin, 1990). 질문의 범주는 일반적인 
Table 1. Characteristics of research participants

\begin{tabular}{|c|c|c|c|c|}
\hline Participant & Sex & Age & $\begin{array}{c}\text { Time of } \\
\text { onset }\end{array}$ & Job \\
\hline 1 & Male & 27 & 24 & Office work \\
\hline 2 & Female & 52 & 51 & House work \\
\hline 3 & Male & 29 & 10 & Service work \\
\hline 4 & Female & 48 & 44 & House work \\
\hline 5 & Female & 38 & - & House work \\
\hline 6 & Male & 25 & 20 & Student \\
\hline 7 & Male & 43 & - & Office work \\
\hline 8 & Male & 31 & 10 & - \\
\hline 9 & Male & 43 & 37 & Office work \\
\hline 10 & Female & 63 & 58 & Teacher \\
\hline 11 & Female & 43 & 20 & Office work \\
\hline 12 & Female & 43 & 42 & Office work \\
\hline 13 & Male & 40 & 30 & - \\
\hline 14 & Male & 38 & 19 & Office work \\
\hline 15 & Male & 51 & 12 & Office work \\
\hline 16 & Male & 31 & 30 & - \\
\hline 17 & Male & 25 & - & Student \\
\hline 18 & Male & 45 & 41 & Office work \\
\hline 19 & Female & 36 & 28 & House work \\
\hline 20 & Female & 58 & 57 & Service work \\
\hline 21 & Male & 28 & 23 & Office work \\
\hline
\end{tabular}

Table 2. Core contents of the in-depth interview

\begin{tabular}{cc}
\hline \hline Category & \multicolumn{1}{c}{ Contents } \\
\hline Recognition & $\begin{array}{c}\text { - What do you think physical activity means } \\
\text { for people with AVI? } \\
\text { - What do you think about people with AVI } \\
\text { participating physical activity around? }\end{array}$ \\
\hline Experience & $\begin{array}{l}\text { - What are the difficulties in participating in } \\
\text { physical activity? }\end{array}$ \\
& $\begin{array}{l}\text { - What is the exercise that I really want to try } \\
\text { but can not do now? }\end{array}$ \\
\hline \hline
\end{tabular}

내용에서 심층적인 내용으로, 공식적인 지식에서 개인적 인 지식으로 좁혀가면서 면담을 진행하였다. 질문에 포함 된 내용은 기존에 수행되었던 연구를 참고하여 구성한 것 으로 중도시각장애인의 신체활동 참여를 촉진 및 제한하 는 사회 심리적 배경에 관한 것들이다. 자료수집 기간은 2017년 6월부터 2017년 12월까지 총 6개월에 걸쳐 연구 자와 $1: 1$ 로 이루어졌다. 면담시간은 연구참여자당 짧게 는 30 분에서 길게는 90 분까지 이루어졌다. 수집된 자료 는 Strauss \& Corbin(1998)이 제시한 개방코딩(open coding), 축코딩(axial coding), 선택코딩(selective coding)과정 분석단계를 따라 분석되었다. 심층면담에서 사용한 반구조화된 면담지의 구체적인 내용은 〈Table 2〉 와 같다.

\section{연구의 진실성 및 윤리}

본 연구에서는 방법적, 해석적, 절차적 오류를 최소화 하기 위해서 구성원간 검토, 동료간 협의를 지속적으로 수행하였다(Lincoln \& Guba, 1985) 연구를 진행하는 과정에서는 연구참여자들에게 연구 절차와 목적을 자세 히 설명하고 동의를 얻는 과정을 거쳤다. 연구자의 이름 은 모두 가명으로 처리할 것이며, 면담 내용은 오직 연구 의 목적으로만 사용할 것을 밝혔다. 또한, 연구 진행과정 중 참여를 중지하더라도 어떠한 불이익이 없음을 충분히 설명하고 개인정보는 모두 부호화 처리되어 보호됨을 사 전에 공지하였다.

\section{연구결과}

\section{중도시각장애인의 신체활동 참여 소외와 극복과정 에 관한 개념과 범주}

본 연구의 개방코딩 결과 총 203 개의 개념이 도출되었 다. 이를 21 개의 하위범주로 구성하였고 하위범주들의 공통되는 주제를 다시 9 개의 상위범주로 범주화하였다. 개방코딩을 통해 얻은 범주화의 결과는 다음과 같다. 
Table 3. Concepts and Categorization

\begin{tabular}{|c|c|c|}
\hline Classification & Category & Subcategory \\
\hline \multirow{3}{*}{$\begin{array}{l}\text { Causal } \\
\text { conditions }\end{array}$} & \multirow{3}{*}{$\begin{array}{c}\text { Poor } \\
\text { accessibility }\end{array}$} & Accessibility of information \\
\hline & & Accessibility of service \\
\hline & & Accessibility of facilities \\
\hline \multirow{5}{*}{ Context } & \multirow{3}{*}{$\begin{array}{c}\text { Depressed } \\
\text { psychological } \\
\text { state }\end{array}$} & Anxiety about the future \\
\hline & & Self-deprecation \\
\hline & & Loss of confidence \\
\hline & \multirow{2}{*}{ Busy day } & Declining business ability \\
\hline & & Insufficient time \\
\hline Phenomena & $\begin{array}{l}\text { Loss of } \\
\text { leisure } \\
\text { experience }\end{array}$ & Abortion of physical activity \\
\hline \multirow{6}{*}{$\begin{array}{l}\text { Intervening } \\
\text { conditions }\end{array}$} & \multirow{2}{*}{$\begin{array}{c}\text { Awareness of } \\
\text { need for } \\
\text { Health care }\end{array}$} & Necessity to maintain balance \\
\hline & & $\begin{array}{l}\text { Recognition of need for weight } \\
\text { control }\end{array}$ \\
\hline & \multirow{4}{*}{$\begin{array}{c}\text { Positive / } \\
\text { Negative } \\
\text { Role of others }\end{array}$} & Loss of exercise partner \\
\hline & & Uncomfortable gaze \\
\hline & & Advice of friends \\
\hline & & Positive role model \\
\hline \multirow{2}{*}{ Strategies } & \multirow{2}{*}{$\begin{array}{l}\text { Expectations } \\
\text { for exercise } \\
\text { effects }\end{array}$} & $\begin{array}{l}\text { Expectations for improved } \\
\text { vision }\end{array}$ \\
\hline & & $\begin{array}{l}\text { Expectations for psychological } \\
\text { effects }\end{array}$ \\
\hline Consequence & $\begin{array}{c}\text { Compromise } \\
\text { on reality }\end{array}$ & $\begin{array}{l}\text { Limited participation in } \\
\text { physical activity }\end{array}$ \\
\hline
\end{tabular}

\section{중도시각장애인의 신체활동 참여 소외와 극복과정에 관한 패러다임 모형}

중도시각장애인의 신체활동 참여 소외와 극복과정에 대한 개념 및 범주에 따른 패러다임 모형은 다음 그림과 같다.

\section{인과적 조건}

열악한 제반시설의 접근성

연구참여자들의 신체활동을 제약하는 직접적인 원인 으로 신체활동 참여를 위한 제반시설 접근성의 부재인 것 으로 나타났다. 이렇게 나타난 열악한 제반시설의 접근성 이라는 인과적 조건은 다시 세 가지 성격의 범주로 나누 어 살펴볼 수 있다. 바로 중도시각장애인들이 참여할 수

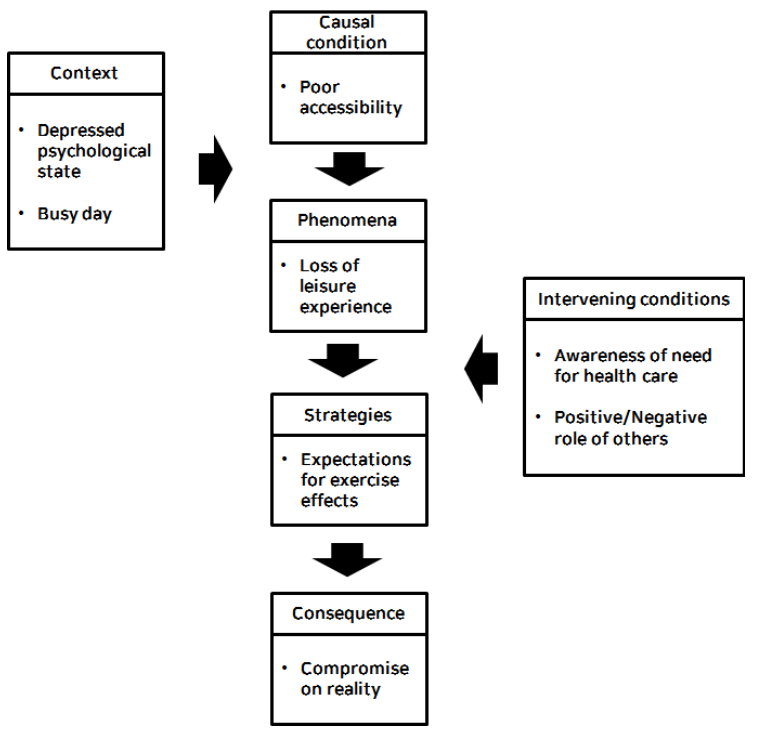

Fig. 2. Paradigm model

있는 운동프로그램 서비스의 부재, 체육시설에 대한 물리 적 접근성의 어려움, 체육시설 및 체육프로그램에 관한 정보의 부재이다. 연구참여자들은 시각장애 등급을 받고 중도시각장애인으로 살아가는 과정에서 신체활동을 지 속할 수 있는 시설이나 서비스에 관한 정보를 행정 기관 으로부터 전혀 접하지 못하고 있는 것으로 나타났다. 장 애등록을 하는 과정에서 얻게 되는 정보는 물질적 혜택에 관한 정보일 뿐이었다, 여가생활을 누릴 수 있는 장소나 서비스 접근에 관한 정보는 부재했다. 또한, 장애인체육 시설이라고 할 수 있는 재활체육시설에서도 중도시각장 애인을 위한 체육프로그램은 개설되지 못한 상태였고 시 각장애인복지관 또한 중증시각장애인을 중심으로 체육 프로그램이 제공되고 있을 뿐, 점차 시력을 상실해가고 있는 중도시각장애인에 대한 이해를 바탕으로 구성된 체 육프로그램은 부재했다. 그래서 연구참여자들은 시력의 상실과 함께 자연스럽게 신체활동으로부터 소외되었다. 연구참여자 19 는 운동을 지속하고자 직접 재활체육센터 에도 방문하여 문의해 보지만, 시각장애인이 이용할 만한 시설과 프로그램을 구비 하고 있지 못하고 있다는 답변만 이 돌아올 뿐이었다.

더 심각한 것은 규칙적인 운동은 둘째 치더라도 일상 적인 신체활동조차 영위할 수 없는 것이 중도시각장애인 
들이 마주하는 현실이었다. 연구참여자 4는 대중교통도 제대로 이용할 수 없는 상황임을 알리며, 일상적인 신체 활동을 위해서 시각장애인들에게는 기본적인 권리라고 할 수 있는 이동권이 보장이 시급함을 시사하였다.

계단도 많고요. 그리고 요즘은 장애인들 편하게 에스컬레이 터 타고, 뭐 그런 걸 만든다고 해도, 지하철 계단에 뭐 이렇 게 '판' 해 가지고 그런 거 있잖아요? 솔직히 그런 거 찾는 것도 힘들고, 작동하는 것도 복잡한데, 되게 힘들잖아요?

(연구참여자 4)

그 앞에 복지관도 제가 물어보니까 없더라고요. 저희 집 앞에 서부재활체육센터에 가서, 그 프론트에 가서 물어봤거 든요. 시각장애인이 이용할 수 있는 거는 없냐고, 그런데, 없대요.

(연구참여자 19)

안 해줘요, 그런 거 없어요. 그냥 장애인 주차 그거하고 혜 택 하는 거. 그다음에 무슨 고속도로 통행료 할인받는 거, 그다음에 공원 같은 거 할인, 장애인 할인 그런 거밖에는. 운동에 대한 그런 안내는 없어요.

(연구참여자 10)

\section{맥락적 조건}

심리적 위축

정안인으로서 삶을 영위했던 연구참여자들의 정체성 이 시각장애인으로 전환되고 난 후 이들이 겪어야 했던 심리적 스트레스는 심각했던 것으로 나타났다. 시력의 저 하로 자신의 기능이 상실되었다고 받아들이고 있는 연구 참여자들은 이전보다 매우 위축된 모습을 보였다. 연구참 여자 6 은 그동안 누릴 수 있었던 다양한 선택권이 제한된 다는 생각에 자신의 처지가 비참하게 느껴질 때가 있다고 하였으며, 연구참여자 15 의 의견을 통해 이러한 부정적 심리감정의 정도가 매우 크다는 사실을 알 수 있다. 이러 한 감정은 그동안 '자연스럽 게' 해왔던 일들이 부자연스러 운 일들이 되어버린 현실의 벽 앞에서 느낀 무력감에 기 반을 둔 것이라 할 수 있을 것이다.

선택권이 줄어들었다고 생각은 안 해요, 그냥 스스로는. 그냥 그러면 너무 좀 그러니까. 약간 비참한 느낌이 들더라고요.

(연구참여자 6)

'나는 왜 이럴까? 나는 왜 이렇게 어떤 장애가 있을까?' 그
런 스트레스를 경험해보지 않은 사람은 몰라요.

(연구참여자 15)

그런 생각이 많이 들더라고요. 그러니까 이게 눈과 귀가 같 이 오니까 받아들이는 정보들이 조금 많이 축소되고, 그러다 보니까 많이 위축되고 그런 것 같습니다. 심리적으로.

(연구참여자 18)

여유 없는 일상

시각기능의 저하로 이들의 일상생활에는 많은 제약이 따르게 된다. 그 중 직장생활에서의 업무능력 저하는 연 구참여자들의 일상의 여유를 빼앗는 주요한 요인으로 자 리 잡게 된다. 시각능력에 제약이 생기다 보니 과거에 짧 은 시간 안에 처리했던 업무를 처리하는데 평소보다 많은 시간과 에너지를 할애하게 되었다. 심리적 위축으로 직장 내 동료에게 적극적인 도움을 청하기 어려운 상황에서 일 을 마치고 나면 이들의 체력은 방전되어 규칙적인 신체활 동에 참여할 심리적 여유를 갖지 못했다. 신체적 심리적 탈진으로 이들은 신체활동 제약을 더욱 심각하게 받아들 였기 때문이다. 이러한 모습은 연구참여자 17 의 의견에 서 구체적으로 살펴볼 수 있다. 연구참여자 17 은 몸은 지 쳐 있는데, 장소와 비용까지 신경을 써가면서 운동을 할 여력이 남아 있지 않다고 하였다. 신체활동 중단에 직접 적인 원인이라고 할 수 있는 열악한 제반 환경이 바쁘고 여유 없는 일상에서 더욱 심각하게 인식된 것이다.

똑같은 근무시간에 해도 일의 효율이 떨어지기 때문에 그거 를 다른 사람한테 좀, 뭐랄까? '내 일을 대신 이거를 좀 해 달라.' 그런 식의 그거를 하기 싫어서 그거를 할 수 있는 방 법은 제가 그들보다 조금 더 일을 하는 수밖에 없어요.

(연구참여자 7)

시간적 여건이 돼야지. 생활 뭐, 운동도 솔직히 시간도 없는 데 운동한다는 자체도 좀.

(연구참여자 11)

이제 시간도 부족하고 갔다 오면 녹초가 되고. 그 다음에 주 변에서 운동을 하려면, 그러니까 보통 헬스장 같은 걸 생각 을 하고 있는데. 일단 장소를 가서, 그러니까 비용 지출해야 되는 것도 있고, 만약에 누군가의 도움이 없으면 그냥 막 운 동을 하다가는 이제 밸런스도 안 맞고 할 수도 있으니까 좀 그런 것도 걱정이 되고 해서 그냥 차일피일 미루다가.

(연구참여자 17) 


\section{중심현상}

여가경험의 상실

시야가 점점 좁아질수록 연구참여자들에게는 일상적 세계는 안전을 위협하는 위험한 환경으로 지각되었다. 평 소 운동을 즐기며 행복함을 누리게 해 주었던 장소들은 다시는 찾지 않은 위험지역이 된다. 다칠지도 모른다는 두려움으로 운동할 수 있는 공간에 접근하기를 꺼리던 연 구참여자들은 기존의 운동을 지속하기 위해 대체할 수 있 는 장소나 운동 종목에 관한 정보를 찾거나 얻지 못하고 결국, 자연스럽게 신체활동을 중단하게 되었다. 이러한 신체활동의 성격은 연구참여자들의 '좋아서 하는' 자발적 인 참여에 의한 '무조건적 여가활동'이었다. 연구참여자 들의 자유는 높고 의미는 내적인 활동이었던 것이다. 이 러한 형태의 신체활동은 매우 긍정적인 정서를 고양하는 삶의 활력소였지만, 신체활동의 중단과 함께 신체활동을 통해 누리던 긍정적 정서경험은 사라졌고, 이들의 상실감 은 컸다.

옛날에는 수영을 다녀도 다닐 수 있었고, 보드를 타고 다녀 도 다녔는데 지금은 그런 이동에 불편함이 있기 때문에 그냥 아예 안 하는 거죠.

(연구참여자 14)

밖에서 자전거 타는 걸 좋아하는 거지. 그래서 그런 것들을 하는 데, 지금은 눈 때문에 아예 그런 걸 시도할 수조차 없어 요. 사고가 날 여지가 너무 크니까.

(연구참여자 7)

지금은 등산은 안 해요, 등산은 왜냐하면 높낮이가 있고 이 렇게 길이 평평치 않으면 잘 안 보여서 걸려서 넘어지거나 그러니까. 그런 험한 길은 잘 안 가죠.

(연구참여자 10)

제가 어릴 때부터 가장 좋아하던 운동이 야구였는데 그거를 못 하니까 아쉬움이 커요.

(연구참여자 9)

\section{중재적 전략}

타인의 긍·부정적 역할

본 연구의 연구참여자들이 시각장애인이 되고 난 뒤에 주변 시선에 대한 불편함을 느껴 이를 지나치게 의식하게 되는 경향이 있었음을 확인할 수 있었다. 먼저 이들은 자
신을 환자로 취급하며 동정하는 외부의 불편한 시선을 감 지하였으며, 외부로부터 표상된 자신의 가상적 정체성과 스스로 생각하는 본인의 고유 정체성 사이에서 갈등을 경 험했던 것으로 보인다. 여기서 연구참여자들이 가지고 있 었던 고유의 정체성은 장애진단 이전의 비장애인으로서 의 자신의 정체성을 뜻한다. 이러한 갈등 상황에서 이들 은 외부에서 제시된 가상의 정체성을 거부하지 못하고 타 인의 시선을 지나치게 의식하게 되며 회피하게 되는 경향 을 보였다. 사회적 시선으로부터 부여되는 정체성을 개인 이 거부하기란 쉬운 것이 아니었던 것이다. 연구참여자 19는 이러한 차별적 시선으로부터 자신뿐 아니라, 자신 의 자녀까지 상처를 받을 수 있음을 인지하고 있었다. 외 부의 부정적인 시선으로 연구참여자들은 외부활동을 꺼 리게 되었다. 즉, 이러한 타인의 불편한 시선이 신체활동 참여의 제약으로 작용한 것이다.

물론 요즘에 그런 의식이 많이 좋아졌다고 해도 아무래도 눈 치를 계속 보게 마련이거든요. 같이 있으면 '저 사람 좀 어 디 안 좋은가 봐?' 이런 것도 있고.

(연구참여자 3)

그러니까 무조건 지팡이를 잡은 자체만으로도 시선 집중이 더라고요. (중략) 아이들이 같이 다니잖아요? 그러면 그 아 이들이 상처가 굉장히 크더라고요.

(연구참여자 19)

필요는 한데(한숨), 이거를 그렇다고 '저 사람이 질환자니까 잘 돌봐야 된다.' 이거는 또 그런 거 같더라고요, 좀 약간.

(연구참여자 6)

연구참여자들은 타인의 부정적인 시선을 불편해하는 동시에 자신의 신체활동 참여에 타인의 긍정적이고 적극 적인 지원을 기대하고 있었다. 다른 어떤 조건보다 자신 의 상황을 이해하는 동료 운동참여자가 있다면, 현재에 당면한 신체활동을 제한하는 제약들을 극복할 수 있다고 생각했던 것이다. 연구참여자 17 은 자신의 신체활동 참 여에 도움을 줄 수 있는 운동전문가의 필요를 절실하게 느끼며 규칙적으로 운동하고 있는 주변 사람을 긍정적인 모델로 받아들임으로써 자신의 건강관리를 위한 운동의 필요성을 인식하였다. 이는 운동 효과에 관한 긍정적 정 보 기여자로서 주변 사람들의 역할을 인정했던 연구참여 
자 12 의 의견에서도 동일하게 나타났다. 타인의 부정 또 는 긍정적인 관여행위가 중도시각장애인들의 신체활동 참여에 영향을 미치는 매우 중요한 요인이라 할 수 있다.

눈이 안 보인다고 하는데 헬스장을 간다고 하면 옆에 누군가 한 명 꼭 있어줘야 할 것 같은 느낌이요. 왜냐하면, 되게 막 쇳소리랑 그런 것이 되게 많이 들리잖아요.

(연구참여자 8)

저는 그냥 개인적으로 누군가가 지속적으로 도움을 줄 수 있 다면 그런 환경이 구애를 받더라도 할 수는 있을 거 같은데. 그러니까 이쪽에 대해서 제대로 알고 계신 분도 없고, 도움 을 주실 수 있는 분도 없으니까. 그래서 좀 포기를 한 거 같 아요.

(연구참여자 17)

네. 그러니까 어느 정도 정기적으로 적어도 하루에 1 시간 이 상 운동한 애들은 좀 더 뭔가 다르다는 걸 느껴서 필요는 하 겠구나, 라고 생각은 하고 있었죠.

(연구참여자 17)

그러니까 이제 뭐 이렇게 주위에서 애기하면 다이어트도 막 계속 시도하게 되고 이러잖아요? 운동도 마찬가지인 것 같 아요. '이거 하니까 참 좋더라.' 막 같이 이런 부분들을 애기 를 해주고. 그다음에 이제 본인이 좋았던 것들 애기를 해주 면 저도 옆에서 같이 좀 많이 하게 되는 것 같더라고요

(연구참여자 12)

건강관리 필요성 인식

사회적이고 물리적인 신체활동의 제약으로 비 신체활 동적 생활습관에 젖어가던 연구참여자들은 자신의 건강 에 이상이 생기고 있음을 감지한다. 본 연구를 통해 이들 이 느꼈던 건강상의 문제는 크게 체중조절의 어려움과 평 형능력의 저하인 것으로 나타났다. 연구참여자들은 이러 한 두 가지의 건강상의 문제점들 시각능력과 관련지어 이 해하고 있었다. 즉, 자신의 건강상의 문제가 시력기능의 저하에 의한 것이며, 이러한 문제가 다시 시력기능에 악 영향을 미칠지도 모른다는 시력능력과 전반적인 건강기 능의 악순환 관계를 염려했던 것이다. 이러한 건강관리의 필요성은 신체활동참여에 대한 의지 또는 동기라고 할 수 있는 운동 효과에 대한 기대감으로 전이되었다.

눈 안 좋은 사람들은 평형감각이 또, 평형감각도 떨어지는 느낌이에요. 그냥 걷는 것도 다른 사람은 어떤지 모르겠지만
나 같은 경우에는 걷는 거 자체도 평형감각이 자꾸 떨어지는 거 같아요. 그래서 그거를 가만히 있으면 안 될 거 같더라고.

(연구참여자 15)

아! 그러니까 지금의 뭐죠? 많이 나가는 체중하고, 체지방도 역시 많은 것이 또 저런, 뭐죠? 다른 병을 유발할 수가 있고. 성인병 같은 걸 또 유발할 수 있고. 그것이 그런 병의 합병증 이 또 눈에 영향을 줄 수도 있기 때문에. 그리고 또 제가 생 활하는데 불편하기도 하고, 지금. 체중이 많이 나가고. 또 겉모습도 썩 좋지 않은 것 같고. 그러니까 그렇죠.

(연구참여자 21)

\section{작용/상호작용 전략}

운동 효과에 대한 기대

연구참여자들은 개인적으로는 비 신체활동적 생활습 관으로 악화된 자신의 건강상태를 인지함과 동시에 사회 적으로는 주변 지인을 통해 운동의 긍정적 효과에 대한 정보를 접하게 된다. 자신의 주관적 건강상태에 대한 평 가와 운동 효과에 대한 정보가 결합하면서 운동에 대한 기대감을 형성하게 된다. 그래서 이들은 신체활동이 줄 수 있는 긍정적인 효과에 대한 기대감을 품고 이를 통해 자신이 현실에서 당면하고자 하는 신체 및 정신적 어려움 을 극복하고자 한다. 신체활동이 이들의 삶에 희망이 된 것이다. 연구참여자 21 의 의견을 통해 중도시각장애인으 로서의 삶을 살아가면서 겪는 정신적인 고통을 분산하는 데 신체활동이 큰 도움이 된다고 이야기하며, 정신적 스 트레스의 완화 도구로서 운동의 역할을 기대했다. 마찬가 지로 연구참여자 5 는 시력개선에 직접적인 영향을 줄 수 있는 긍정적 요인으로서 신체활동의 효과를 기대했다. 이 러한 기대감은 연구참여자들이 당면한 신체활동제약의 요인들을 극복하게 되는 강력한 내적 동기로 작용하게 된다.

그러니까 왜냐하면, 운동한다는 것이 어찌 됐든 신체에 또, 기존의 신체 능력에서 감당할 수 없는 어떠한 고통을 주는 것이기 때문에 그쪽으로 생각하게 되니까 다른 생각을 할 겨 를이 없게 됩니다.

(연구참여자 21)

네, 요새 더 심한 편이거든요. 쉽게 피로를 느겨지고 그러니 까 눈이 더 침침해서 잘 안 보이더라고요. 체력을 좀. 운동 하면 체력이 좀 향상돼서 근력이 강화되니까 피로감이 덜하 면 시력이 그래도 침침한 게 덜 할 수 있을 거 같아서.

(연구참여자 5) 


\section{결과}

\section{현실과의 타협}

운동 효과에 대한 기대감으로 자신을 둘러싼 환경적 제약을 극복해서라도 운동에 참여해야겠다는 결심을 한 연구참여자들은 자신의 제한된 환경 내에서 신체활동을 실행하게 된다. 그러나 여러 현실의 제약으로 시각장애인 이 되기 전 자신이 즐겨하던 유형의 신체활동을 영위하지 못한 채 자신이 처한 상황에서 참여 가능한 활동을 제한 적으로 선택하게된다. 이렇게 참여하게 된 신체활동의 형 태는 즐거움의 목적만을 위해 참여하는 무조건적 여가가 아닌 신체나 정서의 재활적 측면이 강한 회복을 위한 여 가적 특성을 보인다. 이러한 형태의 여가는 소극적 여가 라 할 수 있는데, 신체활동의 즐거움 자체가 목적이 되지 않기 때문이다. 즉, 도구적 기능으로서 신체활동을 영위 하게 되는 것이다. 그러다 보니 연구참여자 18 의 의견처 럼 신체활동이 자발적 참여를 통한 지속적인 참여로 이어 지기가 쉽지 않았다. 건강관리를 위해 신체활동에 참여하 기는 하지만, 과거에 누렸던 여가경험을 회복하지는 못한 것이다.

그래서 제일 큰 게 이제 고민, 고민 지금도 하고 있어요. 현 실적으로 도저히 안 되니까. 자전거라든가 구기종목 이런 거 는 도저히 나는 이제 누구 말대로 눈이 좋아지지 않는 이상 안 되니까. 그냥 냉정하게 인식하고 자꾸. 집에서 할 수 있 는 운동을 좀 찾아보자. 제일 먼저.

(연구참여자 7)

건강관리 차원에서 이렇게 하려고 하면 그게 지속성이 저한 테는 좀 필요하거든요, 그게 의지. 재미있게 하면 할 수 있 을 것 같은데 좀 그냥 단순하게 이렇게 하는 것들은 그런, 자발적인 게 아니니까.

(연구참여자 18)

\section{중도시각장애인의 신체활동 참여 소외와 극복과정 에 관한 범주의 속성 및 차원과 핵심범주}

\section{범주의 속성과 차원}

본 연구의 핵심범주를 중심으로 각 범주들의 속성과 차원을 정리하면 Table 4와 같다.
Table 4. Concepts and Categorization

\begin{tabular}{c|c|c|c}
\hline \hline Classification & Category & Characteristic & Dimension \\
\hline $\begin{array}{c}\text { Causal } \\
\text { conditions }\end{array}$ & $\begin{array}{c}\text { Poor } \\
\text { accessibility }\end{array}$ & Condition & $\begin{array}{c}\text { Good } \leftrightarrow \\
\text { Bad }\end{array}$ \\
\hline \multirow{2}{*}{ Phenomena } & $\begin{array}{c}\text { Depressed } \\
\text { psychological } \\
\text { state }\end{array}$ & Degree & $\begin{array}{c}\text { Great } \leftrightarrow \\
\text { Little }\end{array}$ \\
\cline { 2 - 4 } & $\begin{array}{c}\text { Busy day } \\
\text { leisure } \\
\text { experience }\end{array}$ & Condition & $\begin{array}{c}\text { Good } \leftrightarrow \\
\text { Bad }\end{array}$ \\
\hline $\begin{array}{c}\text { Intervening } \\
\text { conditions }\end{array}$ & $\begin{array}{c}\text { Awareness of } \\
\text { need for } \\
\text { health care }\end{array}$ & Degree & $\begin{array}{c}\text { Great } \leftrightarrow \\
\text { Little }\end{array}$ \\
\cline { 2 - 4 } & $\begin{array}{c}\text { The role of } \\
\text { others }\end{array}$ & Influence & $\begin{array}{c}\text { Positive } \leftrightarrow \\
\text { Negative }\end{array}$ \\
\hline \multirow{2}{*}{ Strategies } & $\begin{array}{c}\text { Expectations } \\
\text { for exercise } \\
\text { effects }\end{array}$ & Level & $\begin{array}{c}\text { High } \leftrightarrow \\
\text { Low }\end{array}$ \\
\hline Consequence & $\begin{array}{c}\text { Compromise } \\
\text { on reality }\end{array}$ & Attitude & $\begin{array}{c}\text { Resistance } \\
\text { Acceptance }\end{array}$ \\
\hline \hline
\end{tabular}

\section{여가경험의 상실}

연구의 중심 주제를 대변하는 핵심범주(core category) 는 신체활동을 제약하는 제반시설의 접근성 저하로 신체 활동을 중단하게 되며 느끼는 여가경험의 상실이다. 연구 참여자들이 경험했던 신체활동을 통한 여가의 의미는 그 자체로 목적의 의미를 갖는 무조건적인 여가의 의미가 강 했다. 삶의 활력소라고 할 수 있는 신체활동을 통한 여가 경험을 상실했던 연구참여자들은 정신 및 신체건강에 위 협을 느끼게 되었다. 중심현상은 이후 중재전략의 개입을 통해 신체활동의 제약을 극복하여 다시 신체활동참여라 는 결과로 전환되는데, 이때 신체활동참여의 의미는 스트 레스 해소나 건강유지를 위한 회복으로서의 여가적 의미 를 내포하게 된다. 즉, 중단되었던 신체활동에 참여하기 는 하지만, 중도시각장애인이 되기 전에 즐기던 여가 경 험을 포함하고 있는 신체활동은 아닌 것이다. 이런 형태 의 신체활동은 정신건강과 신체건강의 회복을 목적으로 하는 도구적 의미로서의 신체활동으로 이해해볼 수 있다. 


\section{논 의}

본 연구는 중도시각장애인의 신체활동 소외현상의 원인 과 극복과정을 탐색하고자 진행되었다. 연구목적을 달성 하기 위해 질적연구전통 중 하나인 근거이론(Grounded Theory) 연구방법을 사용하였으며 총 21명의 연구참여 자와 반구조화된 면담지를 사용하여 심층면담을 진행하 였다. 그 결과 총 203 개의 개념이 도출되었고, 이를 21 개 의 하위범주로 구성하였으며 하위범주들의 공통되는 주 제를 다시 9 개의 상위범주로 범주화할 수 있었다. 본 연 구의 결과를 통해 이력성 시각장애인이라고 할 수 있는 망막색소변성 중도시각장애인의 신체활동 참여를 방해 하는 심리, 사회적인 요인들을 발견해낼 수 있었다. 또한, 이러한 요인들 간의 관계를 패러다임 모형을 통해 이론적 으로 조직화해봄으로써 망막색소변성 중도시각장애인의 신체활동 참여 소외현상에 대한 총체적인 이해를 시도해 볼 수 있었다는데 선행연구와 차별되는 본 연구만의 의의 가 있었다고 판단한다. 지금부터는 본 연구를 통해 도출 된 결과들이 선행연구들과의 관계 속에서 어떠한 의미가 있는지 이론적 차원에서 논의를 진행해보고자 한다.

체육 활동 및 시설에 대한 열악한 접근성은 중도시각장 애인들의 신체활동 소외현상에 직접적인 영향을 미치고 있 는 것으로 나타났다. 이는 신체활동 참여 기회에 대한 정보 의 부족(Stuart, Lieverman, \& Hand, 2006), 시각장애인 을 위한 운동전문가의 부족(Lieberman, Houston-Wilson, $\&$ Kozub, 2002)의 요인을 시각장애인의 신체활동을 제 한하는 주요인으로 지목한 선행연구의 결과와 일치한다. 또한, 설문조사를 통해 시각장애인의 여가제약에 영향을 미치는 요인을 탐색한 $\operatorname{Kim}(2016)$ 의 연구결과와도 비슷 한 결과이다. 해당연구에 참여했던 시각장애인들은 여가 활동시설의 접근권과 이동권 등 장애 여건에 합당한 물리 적 환경이라고 할 수 있는 '장애인지원환경'을 '심리적 불 편'이나 '대인적 제약'보다 자신의 여가제약의 가장 큰 원 인으로 인식하고 있었다. 같은 맥락에서 $\mathrm{KoO} \&$ $\mathrm{Oh}$ (2012)의 시각장애인 생활체육참여 제약요인 조사 연구에서도 환경요인, 사회적 지원 요인, 이동요인 등과 같은 '접근성'의 문제가 중도시각장애인의 주요한 여가제 약요인으로 논의된 바 있다.

신체활동에 대한 '접근성'의 문제는 물리적 문제 자체
로 남아 있는 것이 아니라 시각장애인들의 심리와 상호작 용하며 이들의 운동참여 동기를 저하한다는 데 그 문제의 심각성이 있다. 기대가치이론(Expectancy-value theory)에 따르면 개인은 마주하는 상황에 대한 믿음과 가치에 대한 평가를 바탕으로 자신의 태도를 개발 및 수 정한다. 이러한 이론을 바탕으로 신체활동참여에 제한요 인으로 작용할 수 있는 물리적 환경에 대한 연구참여자들 의 인식이 이들의 신체활동참여를 제한하는 직접적이고 개인적인 심리적 원인으로 작용한 것으로 해석해볼 수 있 다(Kirk, 2019). 따라서, 중도시각장애인의 신체활동량 을 높이기 위해서는 무엇보다 중도시각장애인들이 인식 할 수 있을 정도의 신체활동에 대한 '접근성'의 개선이 이 루어져야 함과 동시에 개선사항에 대한 적극적인 홍보와 교육이 수반되어야 할 것이다.

시력의 제한으로 이전보다 많은 에너지를 일상업무에 쏟아야 했던 연구참여자들은 여유시간 없이 매우 바쁜 하 루를 보내야 했고, 일상에서 선택할 수 행동의 폭이 좁아 졌다는 생각에 이들은 무력감은 컸다. 이런 상황 속에서 신체활동참여를 제한하는 환경적 요인들은 이들에게 더 욱 심각하게 다가올 수밖에 없었다. 그래서 연구참여자들 은 신체활동으로부터 소외된 채 여가경험을 상실하게 되 었다. 이력성 중도시각장애인이 신체활동 참여를 중단하 게 되는 이러한 일련의 과정에 대한 이해는 단편적인 결 과로 환경적 요인을 신체활동 제한의 원인으로 지목했던 선행연구의 제한을 보완해줌과 동시에 시각장애인의 신 체활동 제약의 주요한 원인으로 제시되고 있는 인과 조건 의 성격을 더 깊이 이해해볼 수 있다. 본 연구와 선행연구 의 결과를 통해 제시되고 있는 동일한 결과들은 중도시각 장애인의 신체활동 제약의 문제를 해결하기 위한 정책적 개입이 장애당사자 개인보다는 먼저 이들이 살아가고 있 는 물리적 사회적 환경을 대상으로 더욱 급진적으로 이루 어져야 함을 시사한다. 이와 동시에 신체활동적 생활습관 을 장려 또는 유지하기 위해 시력이나 시야를 상실해가기 시작하는 시점에 있는 중도시각장애인을 대상으로 집중 적인 신체활동 지원 서비스가 제공될 필요가 있다.

중도시각장애인들은 신체활동참여 기회로부터 소외당 함으로써 이전에 누렸던 무조건적인 여가경험을 상실하 게 되었다. 본 연구에서 나타난 중심현상이라고 할 수 있 는 무조건적 여가경험을 상실한 중도시각장애인들의 상 
태는 Lee(2016)의 연구에서 제시된 시각장애인의 '스트 레스' 라는 범주와 관계가 있는 것으로 이는 신체적 이상 을 뜻하는 외적 스트레스와 심리적 이상을 뜻하는 내적 스트레스라는 하위 범주로 구성되어 있다. 먼저 내적스트 레스라는 범주에는 '고립감과 외로움'이라는 부정적인 정 서상태가 내포되어 있었다. 여가경험의 상실 상태가 이러 한 부정적 감정과 정확하게 일치하는 것이라고는 할 수 없지만, 행복감이라고 할 수 있는 여가경험의 부재한 심 리상태는 시각장애인들의 고립감과 외로움이라는 감정 이 확산되기에 매우 적합한 환경이라고 할 수 있다. 중도 시각장애인들의 여가경험의 상실은 단순한 긍정적 정서 의 상실을 의미하는 것이 아니라 부정적 정서로의 전환을 의미하는 것이다. 한편, 외적스트레스라는 범주는 '건강 이 나빠짐'과 '심혈관 질환'이라는 건강문제와 관련한 내 용들을 포괄하고 있는데, 중재적 전략으로 '건강관리 필 요성 인식'이라는 범주가 도출되었음을 고려해 보면, 이 러한 건강관련 문제를 대변하는 외적스트레스라는 범주 또한 신체활동을 통한 여가경험의 부재와 관련이 있음을 시사한다. 이를 종합해보면 결국 신체활동 중단으로 인한 여가경험의 부재는 중도시각장애인의 정서적 신체적 상 태와 직·간접적인 관계에 놓여 있음을 알 수 있다. 신체활 동 중단으로 인한 여가경험의 상실이 부정적정서를 유발 한다는 점에서 직접적이며, 이로 인해 고립된 생활을 함 으로써 건강상태를 악영향을 미치게 된다는 점에서 간접 적인 영향을 주는 것이다. 따라서, 중도시각장애인들이 여가경험이라고 할 수 있는 긍정적인 정서를 체험할 수 있는 신체활동에 참여할 수 있도록 관련 기관이나 체육시 설에서 제공하는 체육프로그램들을 다양화할 필요가 있 다고 판단한다. 중도시각장애인들이 선택할 수 있는 신체 활동종류의 폭을 넓히는 것이 왜 중요한지는 중도시각장 애인들이 중재적전략과 작용/상호작용전략을 거쳐 신체 활동제약을 극복하고 수동적인 신체활동참여하는 결과 로 이어지는 일련의 과정에 대한 이해를 통해 다시 한번 강조될 수밖에 없다.

여가경험의 상실로 고립된 생활을 이어가던 중도시각 장애인들은 자신들의 정신 및 신체건강에 문제가 있음을 깨닫게 됨으로써 건강관리의 필요성을 인식하게 된다. 이 때, 주변 사람들의 역할이 매우 중요한데, 중도시각장애 인들은 신체활동을 통해 어려움을 극복한 긍정적인 사례
를 알게 되거나 지인을 통해 신체활동에 대한 권유와 지 원을 제시받게 될 때 신체활동 효과에 기대를 품으며 신 체활동의 제약들을 극복해나가게 된다. 그러나 타인들이 중도시각장애인을 차별적 시선으로 바라보며 동정적으 로 대할 때, 이들은 더욱더 사회적으로 고립되어 비 신체 활동적 생활습관을 유지하게 되었다(AyVazoglu, Oh, \& Kozub, 2002). 본 연구의 결과에서 나타난 성인 중도 시 각장애인의 신체활동참여에 대한 사회적 지지의 중요성 은 시각장애아동의 신체활동 참여 요인을 연구했던 Kozub \& Oh (2004)의 연구와 일치하며 신체활동을 함 께 참여할 수 있는 자녀가 있을 때 시각장애 노인의 신체 활동량이 통계적으로 유의미하게 높음을 확인한 Koo \& $\operatorname{Kim}(2011)$ 연구와 동일한 결과이다. 이를 통해 신체활동 에 대한 사회적 지지자의 역할이 아동기나 성인기 그리고 노인기와 상관없이 사회적 존재로서 시각장애인의 신체 활동 참여에 영향을 미치는 주요한 요인으로 작용하고 있 음을 확인할 수 있었다. 따라서, 시각장애 복지관이나 관 련 체육시설에서는 가족참여운동프로그램을 확대할 필 요가 있으며, 시각장애인들이 누릴 수 있는 운동의 효과 에 대한 교육과 함께 신체활동에 참여할 수 있는 운동 파 트너를 매칭 해주는 프로그램들이 제시되어야 할 것으로 보인다.

중도시각장애인들은 긍정적인 주변인들의 도움과 건 강관리 필요성에 대한 공감으로 물리적이고 사회적인 제 약들을 극복하고 다시 운동을 시작하게 된다. 그러나 이 때 참여하게 되는 신체활동의 경험은 장애 이전의 누렸던 즐거움을 내포하고 있지 못했다. 이미 건강을 위한 목적 으로 어쩔 수 없이 제한된 환경 내에서 이루어지는 신체 활동에는 무조건 적 즐거움을 제공하는 여가경험이 부재 했다. 자기 자신의 기호보다는 제한된 환경 조건에 맞는 신체활동에 참여하다 보니 이를 지속하는데 많은 어려움 을 느끼기도 하였다. 여가학적 관점에서 이러한 유형의 신체활동 경험은 Kelly(1982)가 제시한 회복을 위한 여 가(Recuperative leisure)에 해당한다. 회복을 위한 여 가는 개인의 자유는 제한되어 있지만, 건강 회복이라는 개인적 의미는 높은 여가의 형태이다. 일반적으로 자기결 정성 이론을 통해서 잘 알려져 있듯이, 인간행동의 지속 성을 높이고, 행복의 감정이라고 할 수 있는 몰입감 (Flow)을 높이기 위해서는 자율성과 유능감이 전제되어 
야 하지만(Deci \& Ryan, 1985), 이러한 형태의 여가적 의미를 담지하고 있는 신체활동은 신체회복이라는 목적 을 위한 도구적 의미가 강하다 보니 신체 활동의 참여의 지속성이 떨어질뿐더러 몰입감 같은 긍정적인 정서를 제 공하지 못한다. 이러한 제한을 보완하기 위해서는 중도시 각장애인들이 참여할 수 있는 신체활동프로그램의 종류 를 다양화할 필요가 있다. 그뿐만 아니라, 이들이 장애를 직면하기 전 적극적으로 참여했던 신체활동에 이후에도 지속적으로 참여할 수 있도록 기존의 운동 종목을 중도시 각장애인의 특성에 맞게 변형하여 이들에게 적합한 신체 활동 유형으로 재구성하는 것이 필요하다. 다양한 운동 종목을 변형함으로써 중도시각장애인이 참여할 수 있는 신체활동 유형의 폭을 확장하여 이들이 기존에 즐기던 유 형의 신체활동을 지속할 수 있다면, 이들에게 유능 감과 자율성을 보장하여 지속적인 신체활동 참여를 유도함으 로써 사회적 고립을 최소화함과 동시에 정신적 신체적 건 강의 효과적인 관리를 도모할 수 있을 것이다.

\section{결론 및 제언}

본 연구는 중도시각장애인의 신체활동 참여 소외와 극 복 과정에 관한 총체적인 이해를 시도하기 위해 수행되었 다. 총 21 명의 성인 중도시각장애인들과 반구조화된 면 담을 통해 자료를 수집하였으며, 자료 분석결과 다음과 같은 결론과 제언을 제시할 수 있었다.

첫째, 중도시각장애인의 신체활동 소외 현상에 직접적 인 영향을 미치는 요인으로는 이들을 위한 체육시설과 체 육프로그램과 관련 정보의 부재, 그리고 전문 지도자의 부재 등과 같은 열악한 제반환경인 것으로 나타났다. 이 러한 인과적 조건은 중도시각장애인들의 분주한 일상과 위축된 심리상태라는 맥락조건 속에서 신체활동을 통한 여가경험의 상실이라는 현상으로 귀결되었다.

둘째, 건강관리 필요성의 인식 정도와 주변인의 긍정 적인 관여 정도에 따라 중도시각장애인들은 운동 효과에 대한 기대를 품게 되었으며 운동 효과에 대한 기대가 크 면 클수록 이들은 자신을 둘러싼 신체활동의 제약 속에서 자신들이 참여할 수 있는 신체활동을 제한적으로 선택하 게 되었다.
셋째, 중도시각장애인들은 건강개선이라는 목적을 달 성하기 위한 도구로서 신체활동을 다시 참여하게 되었다. 이러한 신체활동의 유형은 단순히 심신의 회복을 목적으 로만 진행되는 신체활동의 형태였다. 그러다 보니 이들의 자율성과 흥미를 내포하고 있지 못한다는 한계로 신체활 동의 지속성을 보장하지 못한다는 제한이 있었다.

이러한 결론을 토대로 한 제언 점은 다음과 같다.

첫째, 중도시각장애인들이 당면한 현실의 제한을 극복 하고 신체활동에 참여할 수 있을 정도로 적극적인 체육관 련 제반시설에 대한 정비가 필요하다. 구체적으로, 시각 장애인들이 접근할 수 있는 운동프로그램에 대한 홍보가 이루어져야 하며, 생활체육시설에 특수체육지도자를 배 치하는 방안이 고려되어야 할 필요가 있다.

둘째, 시각장애 복지관이나 관련 체육시설에서는 중도 시각장애인과 가장 가까운 관계라 할 수 있는 가족구성원 의 신체활동에 대한 인식을 긍정적으로 개선하기 위해 가 족 참여 운동 프로그램을 개발할 필요가 있으며, 시각장 애인들이 누릴 수 있는 운동의 효과에 대한 교육과 함께 신체활동에 참여할 수 있는 운동 파트너를 매칭 해주는 프로그램들이 제시되어야 할 것으로 보인다.

셋째, 중도시각장애인들이 여가경험이라고 할 수 있는 긍정적인 정서를 체험할 수 있도록 관련 기관이나 체육시 설에서 제공하는 체육프로그램들을 종류를 다양화하거 나 이들이 기존에 즐겼던 유형의 신체활동을 변형 및 재 구성하여 제공할 필요가 있다고 판단한다.

\section{참고문헌}

Ayvazoglu, N. R., Oh, H. K., \& Kozub, F. M. (2006). Explaining physical activity in children with visual impairments: A family systems approach. Exceptional Children, 72(2), 235-248.

Deci, E., \& Ryan, R. M. (1985). Intrinsic motivation and self-determination in human behavior. Springer Science \& Business Media.

Geon, K. I, Choi, H. N \& Jeong, J. H. (2017). Research for resilience of people with acquired blindness with grounded theory. Journal of Disability and Welfare, 35, 303-329.

Haegele, J. A., \& Porretta, D. (2015). Physical activity and school-age individuals with visual impairments: A literature 
review. Adapted Physical Activity Quarterly, 32(1), 68-82.

Haegele, J. A., \& Zhu, X. (2019). Physical Activity, Self-efficacy and Health-related Quality of Life among Adults with Visual Impairments. Disability and rehabilitation, 1-7.

Kelly, J. R. (1982). Leisure in later life: Roles and identities. New York: Praeger.

Kim, D. H. (2016). Leisure constraints affecting leisure activities of the blind. The Korean Journal of Visual Impairment, 32(2), $67-85$

Kim, K. S., \& Kim, T. H. (2008). Mediator for Socialization to Sports of People with Visually-Impaired Halfway. Journal of Sports and Leisure Studies, 34(1), 777-788.

Kim, S. Y., \& Yoo, W. K. (2018). A phenomenological study on the post-traumatic growth of those with acquired visual impairment. The Korean Journal of Visual Impairment, 34(1), 41-69.

Kim, S., Shin, D. W., An, A. R., Lee, C. H., Park, J. H., Park, J. H., \& Lee, H. K. (2013). Mental health of people with retinitis pigmentosa. Optometry and Vision Science, 90(5), 488-493.

Kirk, T. N. (2019). Examining the Relationship Between Expectancy-Value Motivation, Barriers, and Physical Activity Engagement Among Adults with Visual Impairments.

Koo, K. M., \& Kim, C. J. (2015). Factors Associated with Physical Activity Participation of Older Adults with Visual Impairment: Focused on 2011 Study on National Survey of the Disabled Person. Journal of the Korean Gerontological Society, 35(1), 51-62.

Koo, K. M., \& Oh, A. R. Analysis on the Factors of Restraints Against Participation in the Lifetime Sport of Visual and Hearing Impairment. Korean Journal of Physical Education, 51(2), 423-430.

Kozub, F. M., \& Oh, H. (2004). An exploratory study of physical activity levels in children and adolescents with visual impairments. Clinical Kinesiology, 58(3), 1-7.

Lee, B. M. (2016). AQualitative Study on the Relationships among Leisure, Stress, Coping Strategies and Adjustment: Focused on Running Experiences of Visually Impaired People. Journal of Tourism Sciences, 40(2), 37-58.

Lieberman, L. J., Houston-Wilson, C., \& Kozub, F. M. (2002). Perceived barriers to including students with visual impairments in general physical education. Adapted Physical Activity Quarterly, 19(3), 364-377.

Lincoln, Y. S., \& Guba, E. G. (1985). Naturalistic inquiry (Vol. 75). Sage.

Ministry of Health and Welfare(2018). Survey of people with disability.

Song, N. H., \& Oh, S. E. (2017). The lived experience of suffering from vision loss in adults with acquired visual impairment. Journal of Korean Association for Qualitative Research, 2, 45-55.

Strauss, A., \& Corbin, J. (1998). Basics of qualitative research. Thousand Oaks.

Strauss, A., \& Corbin, J. M. (1990). Basics of qualitative research: Grounded theory procedures and techniques. Sage Publications, Inc.

Stuart, M. E., Lieberman, L., \& Hand, K. E. (2006). Beliefs about Physical Activity among Children Who Are Visually Impaired and Their Parents. Journal of Visual Impairment \& Blindness, 100(4), 223-234.

Ye, K. H., \& Lee, W. S. (2016). Medical Accessibility Analysis by Optical Store and Ophthalmic Clinic Distribution : Centering on Special and Metropolitan Cities. Journal of Korean Ophthalmic Optics Society, 21(3), 159-171. 


\title{
중도 시각장애인의 신체활동 참여 소외현상 탐색
}

\author{
조가람 ${ }^{1}$, 김준식 ${ }^{2}$, 김연수 $^{3}$, 유형곤 $^{3}$, 조인환 $^{4}$, 마대중 $^{5}$, 김운형 $^{6}$, 홍인환 $^{7}$ \\ ${ }^{1}$ 나사렛대학교, 교수 \\ ${ }^{2}$ 서울대학교, 박사과정 \\ ${ }^{3}$ 서울대학교, 교수 \\ 4순천향대학교천안병원, 교수 \\ ${ }^{5}$ 제주대학병원, 교수 \\ ${ }^{6}$ 신촌김안과의원, M.D \\ 7동탄성모병원, 교수
}

〔목적〕 본 연구는 중도시각장애인의 신체활동 참여 소외와 극복과정과 이에 영향을 미치는 요인을 탐색하 는 것이다. (방법) 연구목적을 달성하기 위해 성인 중도시각장애인 21 명을 연구참여자로 선정하였으며, 반구 조화된 면접방법으로 $1: 1$ 면담을 진행하여 자료를 수집하였다, 자료의 분석은 Strauss와 Corbin이 제시한 근거이론 분석방법에 따라 개방코딩, 축 코딩, 선택코딩의 순서를 따라 이루어졌다. 〔결과) 연구결과 총 203 개의 개념이 도출되었고, 이를 21 개의 하위범주로 구성하였으며 하위범주들의 공통되는 주제를 다시 9 개의 주제로 상위범주화할 수 있었다. 구체적인 연구결과는 다음과 같다. 첫째, 중도시각장애인의 신체활동 소외 현상에 직접적인 영향을 미치는 요인은 체육시설과 체육프로그램 관련 정보 그리고 전문 지도자의 부재 등과 같은 열악한 제반환경인 것으로 나타났다. 이러한 인과적 조건은 중도시각장애인의 '분주한 일상'과 '위축된 심리상태’라는 맥락 조건 속에서 '여가경험의 상실'이라는 중심현상으로 귀결되었다. 둘째, 건강관리 필요성의 인식 정도와 주변인의 긍정적인 관여 정도에 따라 중도시각장애인들은 운동 효과에 대한 기대를 품게 되었으 며 운동 효과에 대한 기대가 크면 클수록 자신을 둘러싼 제약 속에서 제한적으로 신체활동에 다시 참여하게 되었다. 셋째, 이때 참여하게 되는 신체활동의 성격은 건강개선이라는 목적을 달성하기 위한 도구적 의미가 강했다. 이러한 신체활동의 유형은 단순히 심신의 회복을 목적으로만 진행되는 신체활동의 형태이다 보니 이 들의 자율성과 흥미를 내재하고 있지 못했다. 그래서 이들은 지속적인 신체활동의 참여를 유지하는데 어려움 을 겪었다. (결론) 중도시각장애인의 신체활동 보장을 위한 제반 환경에 대한 개선과 정비가 필요하며 시력과 시야를 상실해가는 초기단기에 있는 중도시각장애인에게 집중적인 신체활동 지원서비스가 제공되어야 할 것이 다. 또한, 중도시각장애인 당사자와 보호자를 대상으로 운동의 효과와 가치에 대한 교육과 홍보가 수행되어야 하며 지속적인 신체활동 참여를 위해 운동프로그램을 다양화 및 개발하는 한편 장애 진단을 받기 전 참여했던 운동 종목에 지속적으로 참여할 수 있도록 돕는 방향으로 재정적·정책적 지원이 뒷받침되어야 할 것이다.

주요어: 중도시각장애, 신체활동, 소외 